JPP IPTEK November, Vol. 2, No. 2

ISSN 2620-7745 (online)

https://dx.doi.org/10.31284/j.jpp-iptek.2018.v2i2.305

\title{
Pelatihan Pembuatan Penataan Arsip Berbasis Web di Kelurahan Panjang Jiwo
}

\author{
Lestari Retnawati ${ }^{1}, \mathrm{Nia}_{\mathrm{Saurina}}{ }^{2},{\text { Firman } \mathrm{Hadi}^{3}, \text { Emmy Wahyuningtyas }^{4} \text {, Shofiya Syidada }}^{5}$ \\ 1,2,3,4,5 Program Studi Teknik Informatika Universitas Wijaya Kusuma Surabaya \\ ${ }^{1}$ lestari.047@gmail.com, ${ }^{2}$ niasaurina@gmail.com, ${ }^{3}$ firmanp83@gmail.com, \\ ${ }^{4}$ emmycakep@gmail.com, ${ }^{5}$ cpya12@gmail.com
}

\begin{abstract}
In the era of regional autonomy, with the rapid development of technology in the past, on the one hand, it has a positive impact on the smoothness and ease of carrying out various activities, but on the other hand this development also has a negative impact, especially in the field of filing which needs to be anticipated. The problem faced is the lack of skill level of the village apparatus with the demands of a more dynamic society and the archival management system that is still conventional and manual. Observation of community service was carried out at the Panjang Jiwo Village Office. Panjang Jiwo Village is in the Tenggilis Mejoyo District, Surabaya City, East Java Province, which has an area of 126,570 ha with 43 RTs and $8 \mathrm{RWs}$ and a population of 14,346 people. The full address of Panjang Jiwo Village is on Jalan Sarono Jiwo No. 41, Surabaya. Referring to this problem, the community service program is conducted, especially in the Panjang Jiwo Village by providing the administrative management applications and a web-based filing system. The objective of this program is to arrange administrative management that has been web-based and is expected to be beneficial for the village officials and to add repertoire in the field of archival management by increasing the quality of services to the community.
\end{abstract}

Keywords: Letter archive, Archive management application, Panjang Jiwo Village, Web

\begin{abstract}
ABSTRAK
Di era otonomi daerah, dengan perkembangan teknologi yang begitu pesat belakangan ini, di satu sisi mempunyai dampak positif terhadap kelancaran dan kemudahan dalam melaksanakan berbagai kegiatannya. Tetapi, di sisi lain, perkembangan ini juga menimbulkan dampak negatif, khususnya di bidang kearsipan yang perlu segera diantisipasi. Masalah yang dihadapi adalah minimnya tingkat keterampilan aparatur kelurahan dengan tuntutan masyarakat yang lebih dinamis serta sistem pengelolaan arsip yang masih bersifat konvensional dan manual. Observasi pengabdian masyarakat dilakukan di Kantor Kelurahan Panjang Jiwo. Kelurahan Panjang Jiwo, Kecamatan Tenggilis Mejoyo, Kota Surabaya, Provinsi Jawa Timur yang memiliki luas wilayah 126.570 ha dengan 43 RT dan 8 RW dan jumlah penduduk 14.346 jiwa. Alamat lengkap Kelurahan Panjang Jiwo berada di Jalan Sarono Jiwo No. 41, Surabaya. Berkaitan dengan masalah tersebut, program pengabdian kepada masyarakat dilakukan, khususnya di Kelurahan Panjang Jiwo dengan memberikan bantuan aplikasi pengelolaan administrasi dan sistem kearsipan berbasis web. Tujuan pelaksanaan program ini yang diharapkan adalah tertatanya pengelolaan administrasi yang telah berbasis web, bermanfaatnya kegiatan bagi aparatur kelurahan, serta bertambahnya khazanah dalam bidang manajemen kearsipan yang berupa peningkatan kualitas pelayanan kepada masyarakat.
\end{abstract}

Kata Kunci: Arsip surat, Aplikasi pengelolaan arsip, Kelurahan Panjang Jiwo, Web

\section{PENDAHULUAN}

Kegiatan administrasi di suatu kantor pada dasarnya juga mempunyai suatu hasil seperti unit-unit lainnya. Hasil atau produk dari suatu kantor adalah surat, formulir, dan laporan. Penataan surat, formulir, dan laporan yang dihasilkan dan diterima oleh suatu kantor pada akhirnya akan berhubungan dengan kearsipan. Jadi, kegiatan administrasi pada dasarnya adalah menghasilkan, menerima, mengolah, dan menyimpan berbagai surat, formulir, laporan, dan lain sebagainya.

Arsip mempunyai peranan penting dalam proses penyajian informasi bagi pimpinan untuk membuat keputusan dan merumuskan kebijakan. Oleh sebab itu, untuk dapat menyajikan informasi secara lebih lengkap, cepat, dan benar, haruslah ada sistem dan prosedur kerja yang baik dalam bidang penataan arsip. 
Menurut Barthos (2013:2), kearsipan mempunyai peranan sebagai "pusat ingatan, sebagai sumber informasi dan sebagai alat pengawasan" yang sangat diperlukan dalam setiap organisasi dalam rangka kegiatan "perencanaan, penganalisaan, pengembangan, perumusan kebijaksanaan, pengambilan keputusan, pembuatan laporan, pertanggungjawaban, penilaian dan pengendalian setepat-tepatnya". Arsip berarti juga sesuatu yang tanpa mempedulikan zaman dan bentuknya, di antara segala informasi yang dicatat oleh manusia, informasi yang memiliki nilai sejarah atau budaya dan dipandang perlu untuk disimpan sebagai data sejarah atau sekadar perlu untuk disimpan. Menurut Wursanto (2004:48), sebagai sumber informasi, arsip dapat membantu mengingatkan dalam rangka pengambilan keputusan secara cepat dan tepat mengenai suatu masalah.

Proses penciptaan arsip dengan transformasi digital sering disebut digitalisasi. Secara umum, digitalisasi adalah proses penciptaan arsip elektronik dari arsip konvensional dengan tujuan untuk melindungi arsip konvensional dari kerusakan secara fisik (Budiman, 2009:5).

Mengingat peranan arsip yang begitu penting bagi kehidupan berorganisasi, keberadaan arsip perlu mendapat perhatian khusus. Sehingga, keberadaan arsip di kantor benar-benar menunjukkan peran yang sesuai dan dapat mendukung penyelesaian pekerjaan yang dilakukan semua personel dalam organisasi. Perhatian yang perlu diberikan kepada arsip yang dimiliki organisasi berupa sistem penataan yang benar dan efektif sehingga dapat mendukung efisiensi kerja dalam hal penyediaan informasi.

Kantor Kelurahan Panjang Jiwo adalah sebuah kelurahan di wilayah Kecamatan Tenggilis Mejoyo, Kota Surabaya, Provinsi Jawa Timur. Alamat lengkap Kelurahan Panjang Jiwo di Jalan Sarono Jiwo No. 41, Surabaya. Kelurahan Panjang Jiwo memiliki luas wilayah 126.570 ha dengan 43 RT dan 8 RW serta jumlah penduduk 14.346 jiwa. Kantor Kelurahan Panjang Jiwo merupakan salah satu kantor pemerintahan yang melayani kepentingan umum yang tidak akan lepas dari kegiatan kearsipan.

Penataan arsip ini nantinya dapat mempermudah pegawai untuk mengumpulkan arsip-arsip surat di Kelurahan Panjang Jiwo. Untuk itu, akan dibangun suatu sistem penataan arsip berbasis web sebagai wadah dalam penataan arsip surat sehingga proses pengumpulan arsip yang selama ini kurang efisien dapat berjalan secara efisien.

\section{METODE PELAKSANAAN}

Permasalahan atau kondisi yang ada pada Kelurahan Panjang Jiwo saat ini yaitu arsip, yang berupa surat masuk dan keluar, masih dikelola secara manual dengan menggunakan aplikasi Microsoft Excel maupun Word. Pencatatan data dapat dilakukan pada banyak file yang berbeda yang dapat disimpan pada tempat yang berbeda. Hal ini mengakibatkan kebutuhan waktu yang tidak sebentar pada saat melakukan manipulasi data untuk menyusun laporan.

Dengan adanya penataan pengarsipan berbasis web di Kelurahan Panjang Jiwo, didapatkan manfaatnya sebagai berikut.

a. Mempermudah dalam mengolah data dan informasi yang siap disampaikan, antara lain kepada warga yang membutuhkan. Karena layanan yang berbasis web, penyampaian informasi dapat berlangsung lebih cepat, mudah, murah, serta dapat dilakukan kapan saja, di mana saja.

b. Mengimplementasikan sebuah web untuk layanan di kelurahan yang menyediakan layanan, aplikasi-aplikasi, maintenance system, infrastruktur, dan penyimpanan data secara terpusat di web server.

c. Menghasilkan sebuah CMS (Content Management System) E-Desa berbasis web sebagai public service dengan fitur-fitur serta modul-modul siap pakai, on demand, mampu mengolah informasi, menciptakan keseragaman dalam hal pengolahan informasi. Tapi, pada dasarnya, web memiliki banyak manfaat, selain ramah lingkungan karena tidak menambah sampah, juga cukup membantu mengurangi tumpukan kertas di meja kerja. Ditambah lagi dengan format digital, penyebaran informasi menjadi lebih mudah dan cepat. 


\subsection{Metode Pengumpulan Data}

Metode pengumpulan data yang digunakan dalam penelitian adalah metode yang terdapat dalam Yusi \& Idris (2009:106-112).

\section{a. Observasi}

Observasi digunakan dalam rangka mengumpulkan data dalam pengabdian masyarakat. Tim mengadakan pengamatan secara langsung pada subjek penelitian yang berhubungan dengan sistem penataan arsip di kantor Kelurahan Panjang Jiwo, Kecamatan Tenggilis Mejoyo, Kota Surabaya.

\section{b. Wawancara}

Wawancara dilakukan untuk untuk memperoleh informasi yang mendalam tentang penataan arsip dinamis (Basuki, 2008) di kantor Kelurahan Panjang Jiwo, Kecamatan Tenggilis Mejoyo, Kota Surabaya yang meliputi jenis arsip yang disimpan, sistem penyimpanan arsip yang digunakan, prosedur surat masuk dan keluar, proses penemuan kembali, prosedur peminjaman arsip, pelaksanaan pemeliharaan dan perawatan arsip, serta pengetahuan yang dimiliki pegawai yang mengurusi kearsipan, penyusutan, dan pemusnahan arsip. Selain itu, hal yang berhubungan dengan hambatan-hambatan yang ditemui saat penataan arsip serta upaya yang dilakukan untuk mengatasi hambatan tersebut juga digali. Informasi lain yang dicari yakni berkenaan dengan fasilitas, sistem penyimpanan, petugas kearsipan, serta lingkungan tempat arsip disimpan.

\subsection{Pelaksanaan Kegiatan}

Pelaksanaan Kegiatan dilakukan pada tanggal 29 Juni 2018 di Kelurahan Panjang Jiwo, Kecamatan Tenggilis Mejoyo, Kota Surabaya. Kegiatan dihadiri oleh 12 orang yang terdiri atas Lurah, Sekretaris Kelurahan, dan 10 orang perangkat Kelurahan Panjang Jiwo.

\subsection{Pembuatan Artikel}

Pembuatan artikel dilakukan setelah pelaksanaan kegiatan yang bertujuan untuk mempublikasikan hasil pelaksanaan kegiatan pengabdian kepada masyarakat.

\subsection{Pembuatan Laporan Akhir}

Pembuatan laporan akhir merupakan bagian akhir dari dokumentasi kegiatan.

\section{HASIL DAN PEMBAHASAN}

Surat merupakan salah satu alat komunikasi yang masih digunakan oleh instansi atau perusahaan untuk berhubungan dengan pihak luar sehingga penataan surat harus dikelola dengan baik. Penataan arsip surat masuk dan keluar adalah suatu kegiatan penting bagi sebuah instansi. Kegiatan surat-menyurat harus mendapatkan perhatian yang sungguh-sungguh karena isi surat pada instansi akan menjadi sarana pencapai tujuan instansi tersebut. Maka dari itu, perlu adanya penataan surat yang baik dalam suatu perusaahaan atau instansi. Oleh sebab itu, pemerintah mengeluarkan Peraturan Gubernur Nomor 1 tahun 2011 tentang Penataan Arsip Dinamis, pengurusan surat harus dikembangkan dengan sarana teknologi informasi dan berkembang menjadi sebuah sarana sistem administrasi perkantoran pemerintah daerah.

Aplikasi manajemen arsip surat merupakan sebuah aplikasi yang digunakan dalam melakukan surat-menyurat secara elektronik yang dikirim ke tujuan masing-masing. Selain digunakan untuk komunikasi surat-menyurat, aplikasi manajemen arsip surat ini juga bisa mendisposisikan untuk ditindaklanjuti oleh pegawai yang bersangkutan. Sehingga, aplikasi ini dapat berperan aktif dalam menyampaikan informasi kepada pegawai-pegawai secara cepat dan akurat.

Aplikasi manajemen surat ini diharapkan dapat memudahkan dalam mengarsip surat secara elektronik. Aplikasi manajemen surat ini juga mempermudah pegawai dalam mendapatkan 
informasi terkait pekerjaan. Source code aplikasi manajemen surat ini dibuat dan dikembangkan menggunakan bahasa pemrograman PHP. Penulisan syntax-nya dibuat sedemikian rupa agar mudah dipahami. Sehingga, untuk kedepannya, diharapkan aplikasi ini dapat dikembangkan lebih jauh yang tentunya melihat kebutuhan yang ada. Penataan arsip surat ini tidak lagi berupa hard copy atau lembaran kertas namun sudah berupa file hasil dari pemindaian atau scan dari surat yang asli. Arsip hasil scan akan disimpan dengan kode-kode tertentu untuk memudahkan dalam pencarian sehingga arsip yang masuk beberapa tahun yang lalu tidak rusak dan mudah dicari.

Dengan skema proses yang jelas, tentu aplikasi ini dapat langsung diterapkan untuk dapat membantu dalam melakukan manajemen surat. Ditambah dengan sentuhan desain atau tampilan yang modern, tentu menjadi nilai tambah aplikasi ini.

Di kantor Kelurahan Panjang Jiwo, penataan surat masuk dan surat keluar masih dicatat secara manual dengan dicatat pada buku arsip surat masuk dan keluar. Apabila dibutuhkan, data surat masuk maupun keluar harus dicari satu-persatu di buku arsip dan membutuhkan waktu yang cukup lama. Pencatatan surat hanya tergantung pada buku agenda dan pegawai yang mengelola surat hanya satu orang (pengelola tunggal). Untuk itu, dibuat aplikasi pengarsipan surat masuk dan keluar. Dengan adanya aplikasi surat masuk dan keluar yang berbasiskan komputer, diharapkan proses pencarian data surat masuk dan keluar dapat dilakukan secara cepat karena data-data tersimpan dengan aman dan terstruktur. Selain itu, tidak terjadi lagi keterlambatan dalam pencarian data serta proses pencatatan surat masuk dan keluar. Pembuatan laporan pun akan menjadi cepat dan akurat.

Penataan arsip surat di Kelurahan Panjang Jiwo dapat diakses pada pranala www.panjangjiwo.arsipsurat.net. Sistem administrasi penataan arsip surat masuk dan keluar berbasis web dapat mempermudah pegawai dalam mengelola arsip surat dari tahun ke tahun dengan mudah dan terhindar dari kerusakan arsip. Adanya sistem administrasi penataan surat masuk dan keluar berbasis web mempermudah dalam hal pencarian arsip surat dengan akurat, mudah, dan efisien.

\subsection{Tampilan Penataan Arsip Surat Berbasis Web}

\section{Tampilan Login}

Tampilan Login digunakan sebagai pengaman sistem dari penyalahgunaan hak akses sehingga keamanan data dapat terjamin. User diminta untuk memasukkan username dan password untuk dapat mengakses data selanjutnya. Untuk lebih jelas, proses login dapat dilihat pada pada Gambar 1.

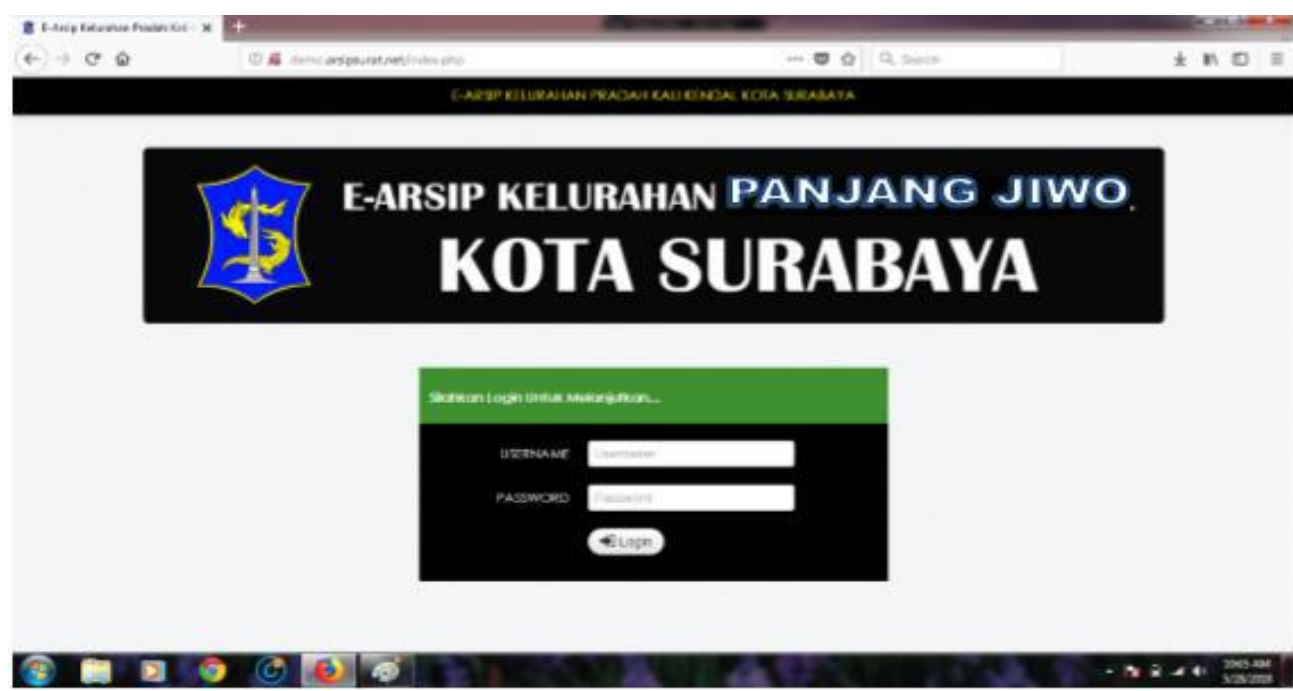

Gambar 1. Tampilan Login 


\section{Tampilan Menu Utama}

Tampilan Menu Utama merupakan beranda yang menampilkan informasi alamat Kelurahan Panjang Jiwo yang dapat dilihat pada Gambar 2.

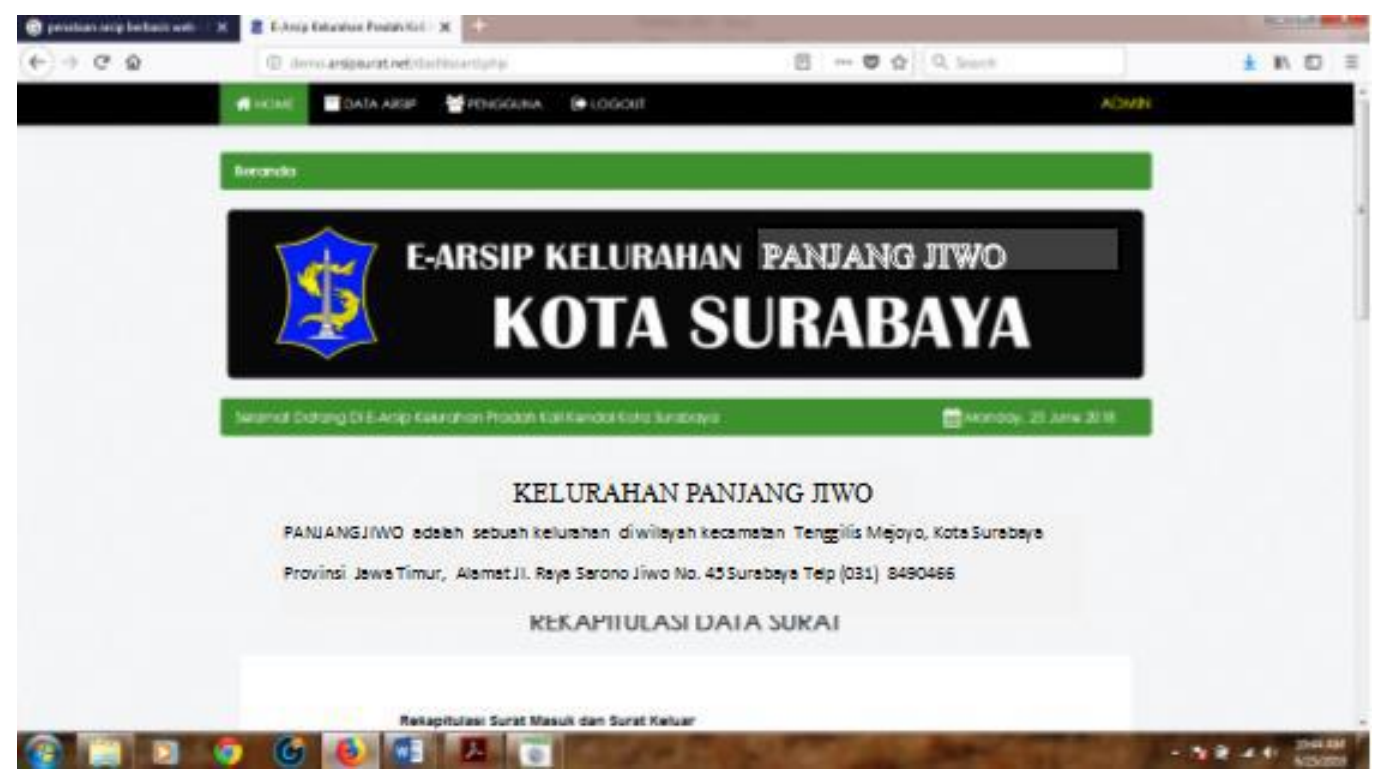

Gambar 2. Tampilan Menu Utama

Tampilan Input Data Surat Masuk

Tampilan Input Data Surat Masuk digunakan oleh perangkat kelurahan untuk memasukkan data surat masuk dengan memasukkan tanggal surat, pengirim, perihal, nama perangkat yang melakukan pengarsipan data, rekaman dokumen yang telah diunduh, dan status tindakan. Status tindakan dapat berupa "Disimpan di arsip" dan "Diteruskan ke Lurah/Kepala Desa" yang dapat dilihat pada pada Gambar 3.

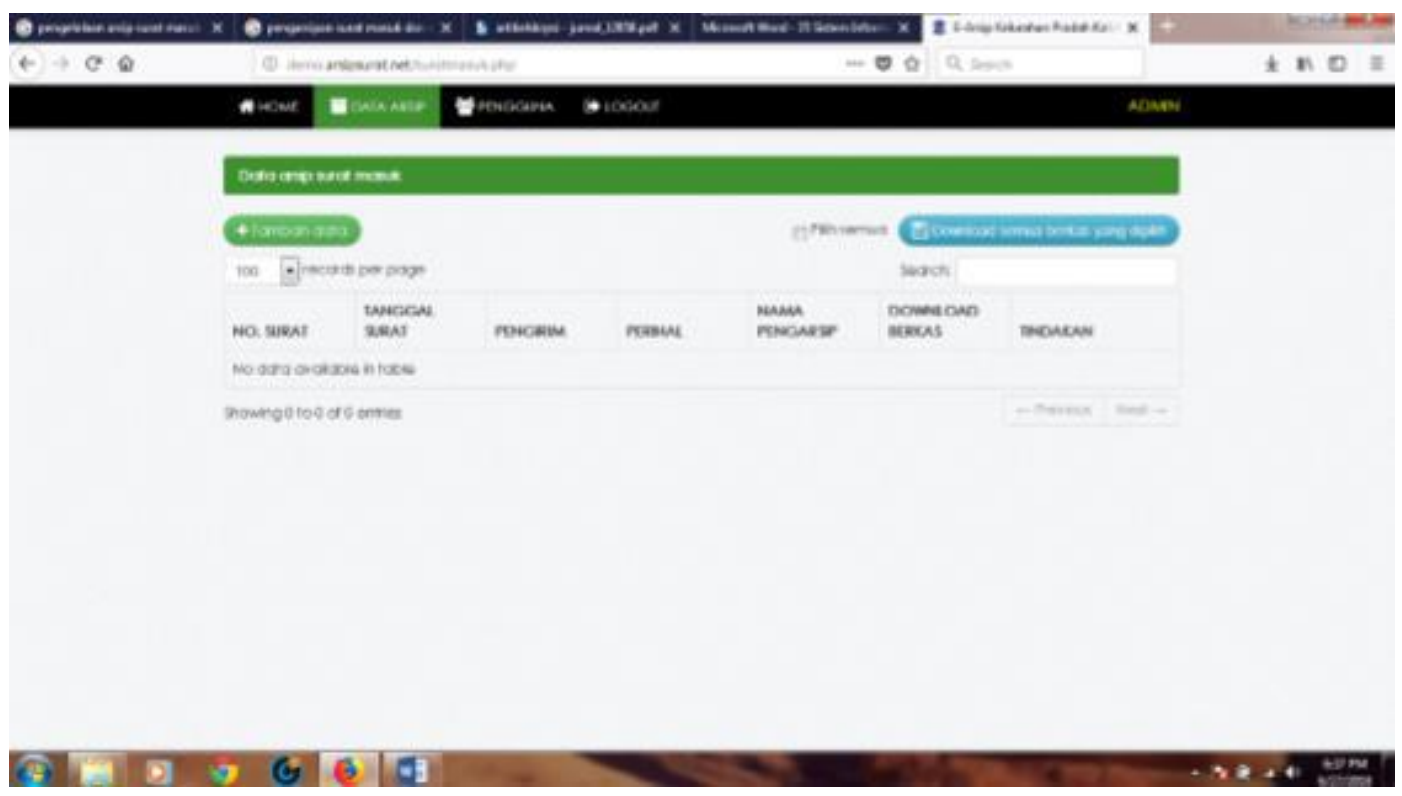

Gambar 3. Tampilan Input Data Surat Masuk 


\section{Tampilan Input Data Surat Keluar}

Tampilan Input Data Surat Keluar digunakan bagi perangkat kelurahan untuk membuat surat keluar yang berisi identitas nomor surat, tanggal surat, tujuan, perihal, nama perangkat yang melakukan arsip data, histori berkas yang diunggah atau dikirim, status tindakan. Status tindakan berupa "Dikembalikan" ke lurah/kepala desa dan "Dikirim" ke tujuan pengiriman yang dapat dilihat pada Gambar 4.

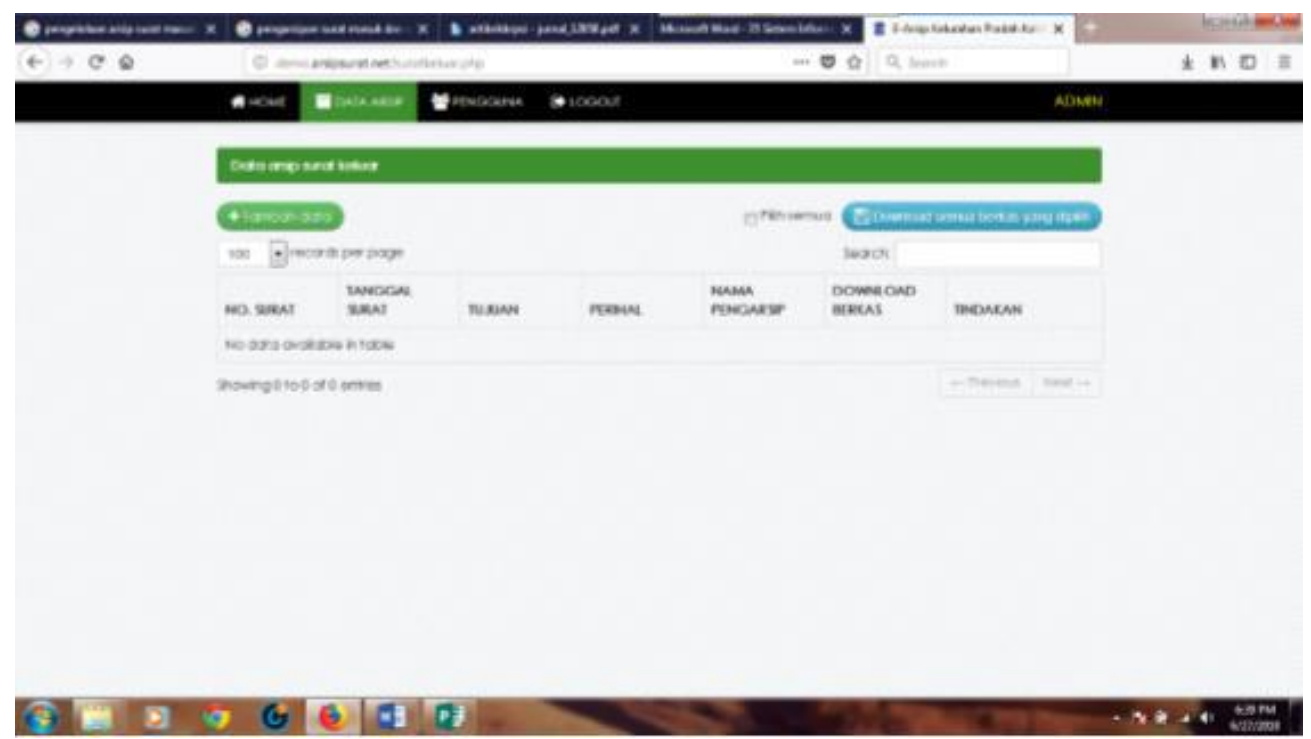

Gambar 4. Tampilan Input Data Surat Keluar

\section{Tampilan Grafik Surat Masuk}

Tampilan Grafik Surat Masuk digunakan untuk menampilkan jumlah surat masuk. Laporan surat masuk berupa grafik dapat dipilih berdasarkan tahun, bulan, dan tanggal yang dapat dilihat pada Gambar 5.

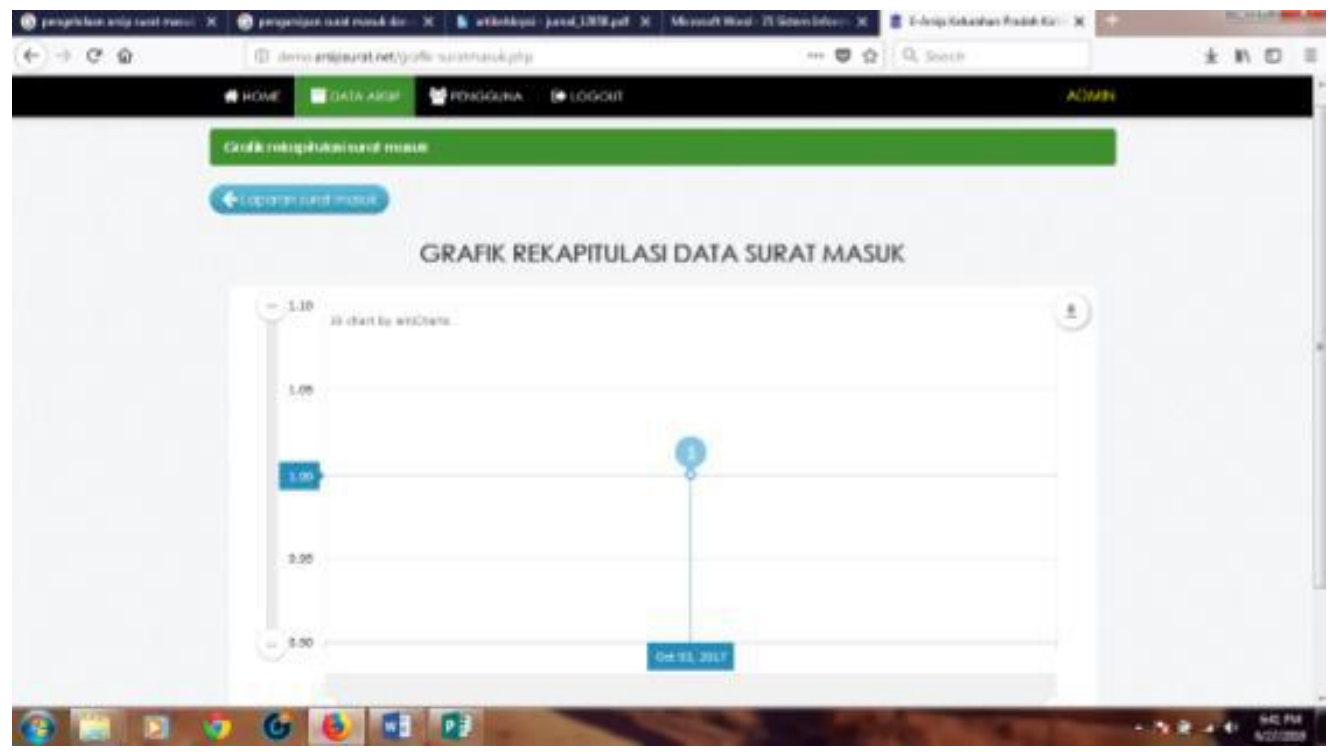

Gambar 5. Tampilan Grafik Surat Masuk

\section{Tampilan Grafik Surat Keluar}

Tampilan Grafik Surat Keluar digunakan untuk menampilkan jumlah surat keluar. Laporan surat keluar berupa grafik dapat dipilih berdasarkan tahun, bulan, dan tanggal yang dapat dilihat pada Gambar 6. 


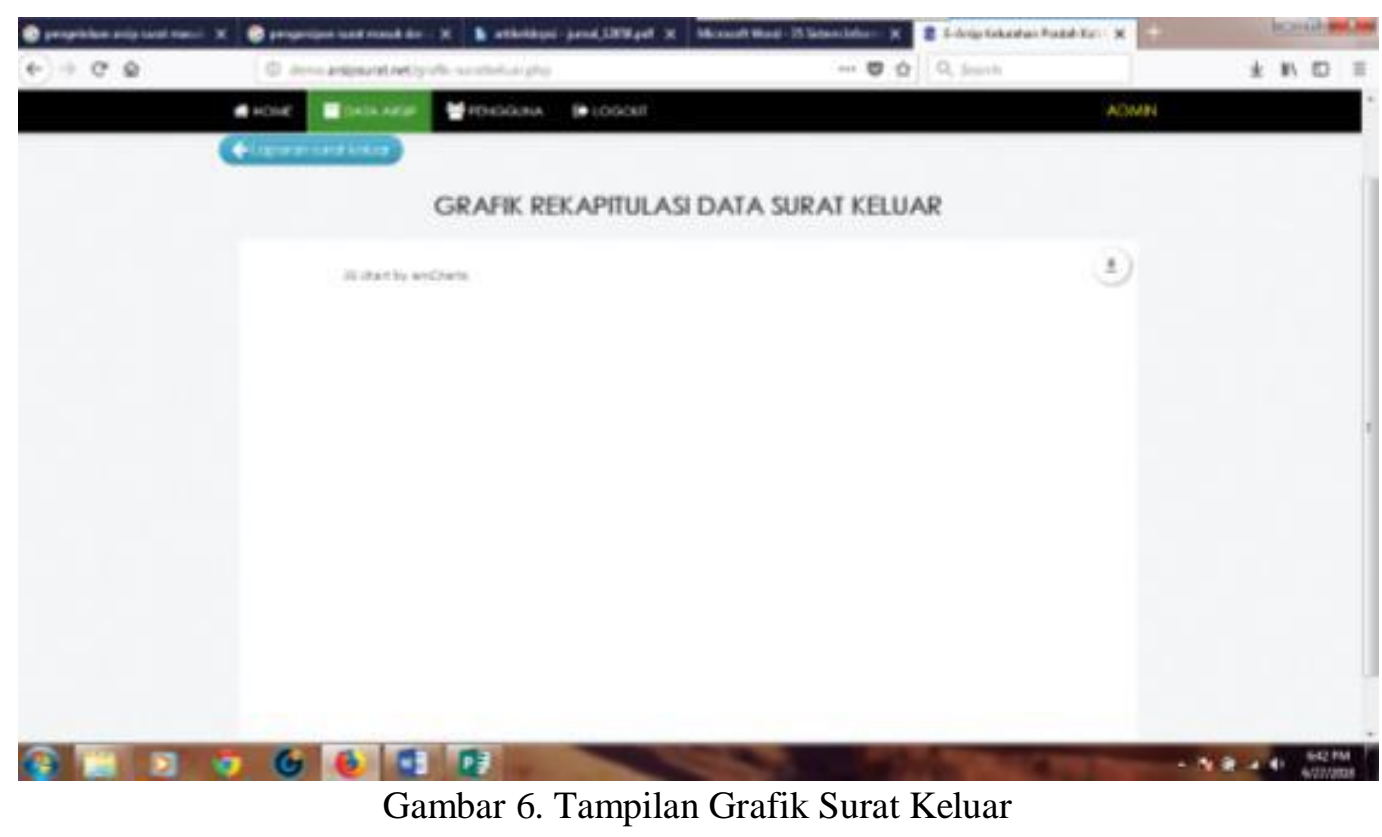

\subsection{Foto-Foto Kegiatan}

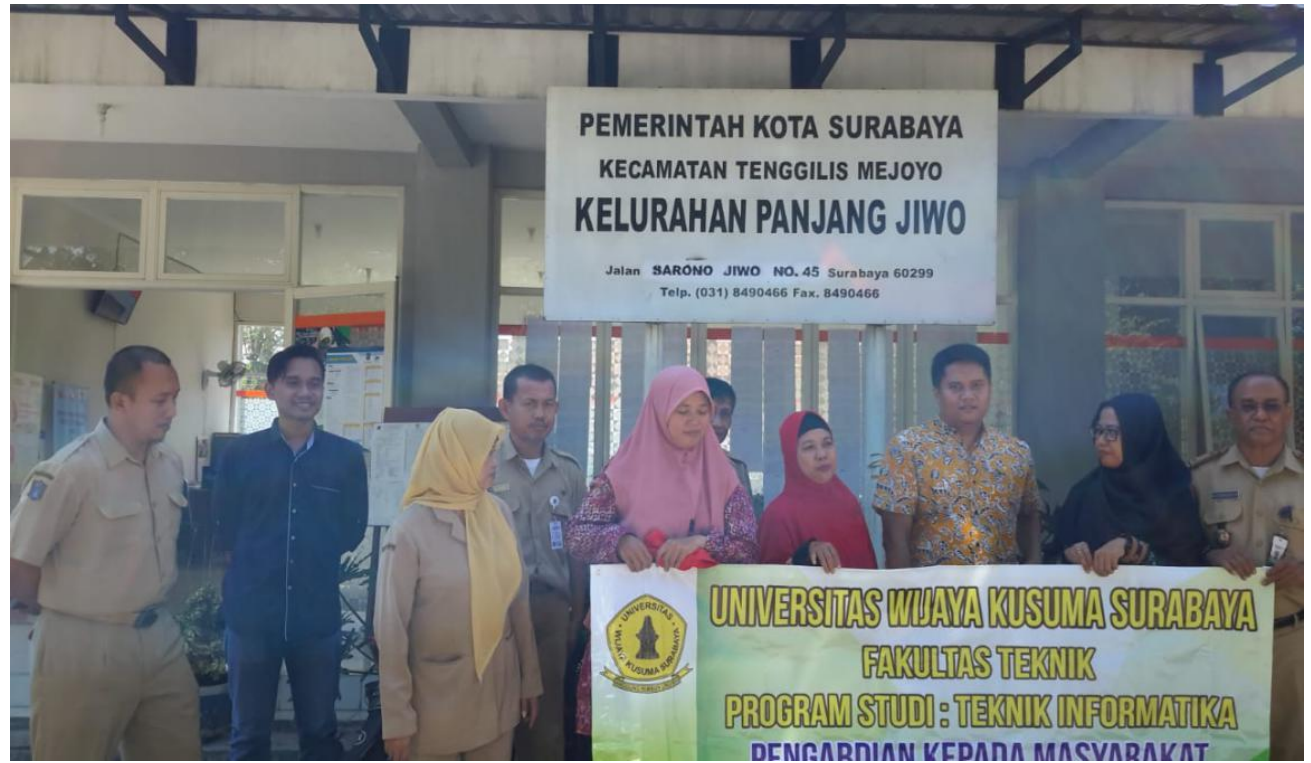

Gambar 7. Kedatangan Tim dari Univesitas Wijaya Kusuma ke Kelurahan Panjang Jiwo

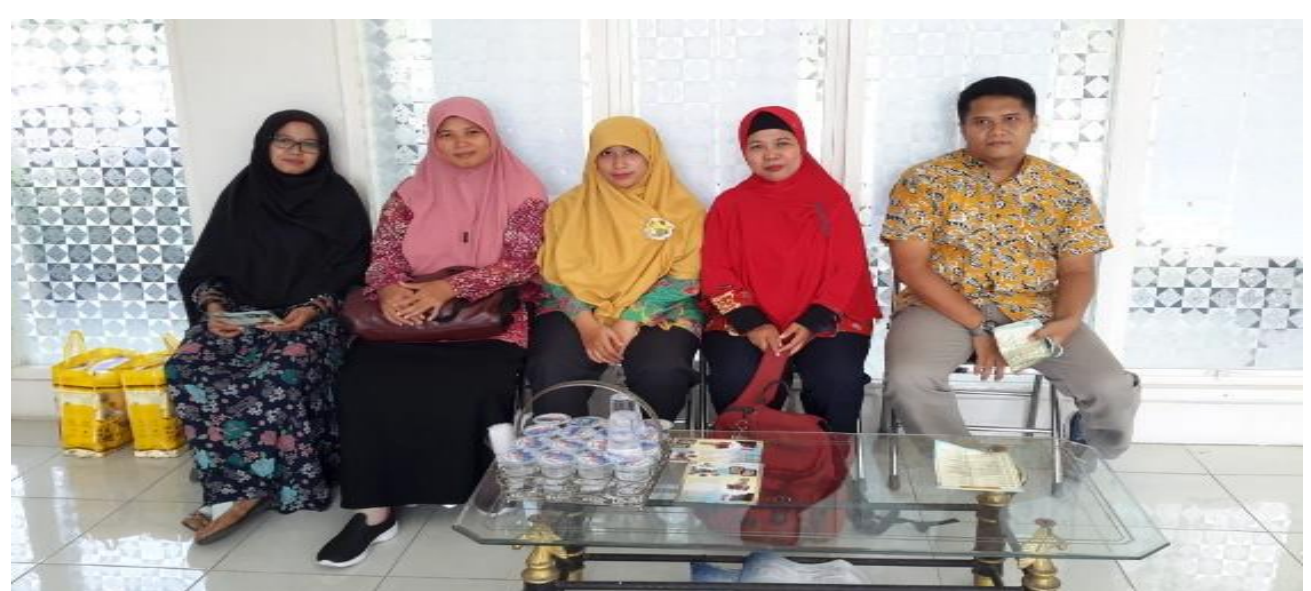

Gambar 8. Pembicaraan Serah Terima Aplikasi Penataan Arsip Berbasis Web 


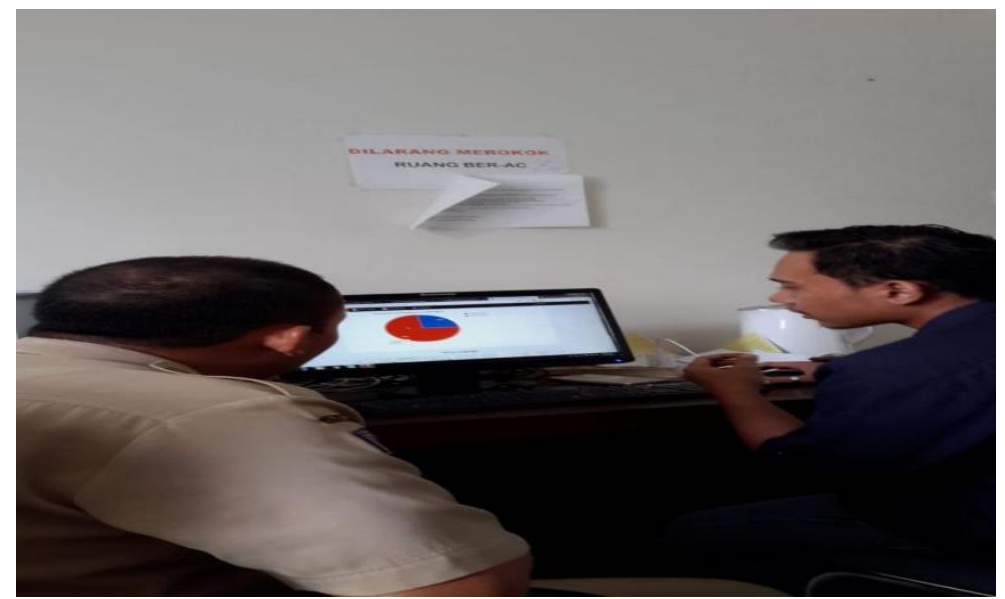

Gambar 9. Pelatihan Pengoperasian Aplikasi Penataan Arsip kepada Perangkat Kelurahan Panjang Jiwo

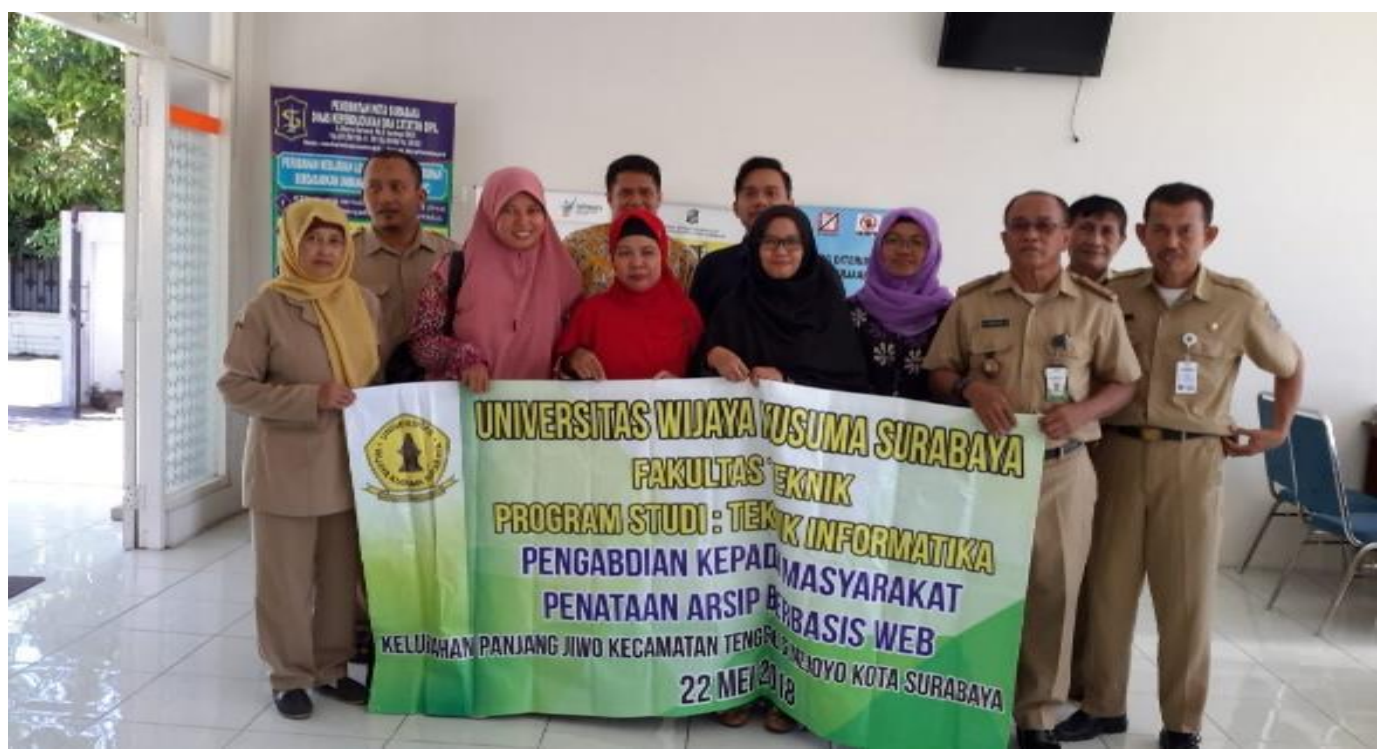

Gambar 10. Foto Bersama Tim dari Universitas Wijaya Kusuma Surabaya dengan Aparat Kelurahan Panjang Jiwo

\section{KESIMPULAN}

Berdasarkan hasil pengabdian kepada masyarakat dapat disimpulkan sebagai berikut.

1) Dengan menggunakan sistem informasi pengarsipan surat masuk dan keluar ini, proses pencarian data menjadi lebih cepat.

2) Adanya analisis sistem surat masuk dan keluar yang berbasiskan komputer dapat meningkatkan produktivitas kerja, khususnya dari segi proses pencatatan surat masuk dan keluar, dan pembuatan laporan akan menjadi cepat dan akurat.

3) Faktor penghambat penataan surat masuk dan keluar yang ada di kantor Kelurahan Panjang Jiwo yaitu kurang sadarnya pegawai akan pentingnya buku agenda surat keluar dan arsip, pegawai yang kurang mahir dalam menggunakan komputer, kurangnya jumlah komputer, printer, dan scanner dalam setiap ruangan, serta kondisi geografis yang menjadi kendala dalam proses pendistribusian surat keluar.

4) Usaha yang dilakukan untuk mengatasi hambatan yang ada di kantor Kelurahan Panjang Jiwo yaitu dengan memberikan motivasi kepada pegawai yang mengerjakan pekerjaan tidak berdasar aturan yang telah diberikan pimpinan, memberikan motivasi kepada pegawai yang kurang mahir dalam menggunakan komputer, serta pemenuhan sarana transportasi untuk pendistribusian surat keluar. 
Berdasarkan kesimpulan, saran yang dapat diberikan di antaranya:

1) Perlu penambahan baki surat, agar surat yang masuk atau yang keluar tidak hanya berserakan di meja atau diselipkan di buku agenda. Perlu penambahan sarana penyimpanan arsip seperti penambahan filing cabinet, map gantung, mesin fotokopi, snelhecter, kotak kartu, yang dapat mempermudah proses pencarian arsip dan proses administrasi.

2) Penambahan lemari besi agar surat dan arsip lainya tidak mudah di ambil oleh pegawai lain yang kurang bertanggung jawab. Keamanan surat dapat terjaga, tidak hanya dimasukkan ke dalam ordner dan dimasukkan dalam rak kayu.

3) Penambahan komputer, scanner, dan printer dalam setiap ruangan agar dalam proses penyusunan surat keluar tidak harus ke ruang lain. Penambahan komputer, scanner, dan printer dapat memperlancar kinerja pegawai.

4) Perlu diadakan pelatihan menggunakan komputer, tidak hanya beberapa bagian saja, tetapi semua pegawai mengingat pekerjaan di kantor Kelurahan Panjang Jiwo menggunakan komputer.

5) Pemberian motivasi yang dilakukan setiap apel pagi agar penataan berjalan dengan baik sehingga pelayanan yang memuaskan akan tercapai.

\section{UCAPAN TERIMA KASIH}

Ucapan terima kasih disampaikan kepada LPPM Universitas Wijaya Kusuma Surabaya yang telah membiayai kegiatan pengabdian masyarakat ini. Terima kasih disampaikan pula kepada Kelurahan Panjang Jiwo, Kecamatan Tenggilis Mejoyo, Kota Surabaya atas kesempatan yang diberikan untuk melakukan kegiatan pengabdian kepada masyarakat.

\section{DAFTAR PUSTAKA}

Barthos, B. (2013). Manajemen Kearsipan (1 ed.). Jakarta: Bumi Aksara.

Basuki, S. (2008). Manajemen Arsip dinamis: Pengantar memahami dan mengelola informasi dan dokumen. Jakarta: Gramedia Pustaka Utama.

Budiman, M. R. (2009). Dasar Pengelolaan Arsip Elektronik. Badan Perpustakaan dan Arsip Daerah Provinsi DIY.

Wursanto, I. (2004). Kearsipan. Yogyakarta: Kanisius.

Yusi, S., \& Idris, U. (2009). Metodologi Penelitian Ilmu Sosial Pendekatan Kuantitatif. Jakarta: Citra Books Indonesia. 